\title{
Implementation of Good Governance and Clean Governance Towards an Effective and Dignity Bureaucracy
}

\author{
Didin Hadi Saputra ${ }^{1}$, Lalu Putra Muhlis², Mikyarul Ilmy ${ }^{3}$, Agus Suparno ${ }^{4}$, \\ M. Nasuhi ${ }^{5}$, Mufidah ${ }^{6}$ \\ 1,3,4,5,6 Nahdlatul Wathan University Mataram, Indonesia \\ ${ }^{2}$ East Lombok Regional Government \\ Email: didinhs@unwmataram.ac.id \\ (Received: January-2021; Reviewed: February-2021; Accepted: March-2021;
}

Avalaible Online: March-2021; Published: March-2021)

(7) (8) This is an open access article distributed under the Creative Commons Attribution License CC-BY-NC-4.0 @2021 by author (https://creativecommons.org/licenses/by-nc/4.0/)

\begin{abstract}
Government governance that will lead to a good level must be continuously promoted and advertised. This campaign must be continuously carried out in order to create a clean and authoritative government and produce dignified officials. The implementation of good govenance is one of the best concepts of offering a system in democracy. The purpose of this research is to find out how the implementation of good services carried out by the state civil apparatus (ASN) in order to create a clean, dignified and good government. The method used in this research is a deft interview, namely in-depth research or qualitative research. Large organizations that run a bureaucratic system will usually have strict procedures, regulations and rules so that their operational processes tend to be less flexible. Today's bureaucracy is found in government organizations, hospitals, companies, schools, and the military.
\end{abstract}

Keywords: governance; good governance; ASN; regulation

\section{INTRODUCTION}

The word good government or good government is a word that is familiar to the ears of the bureaucracy (Indonesia). The framework or concept of good government in the science of government is a must. Good governance is one of the keys or foundations of the government in carrying out a good and professional public service activity. The concept or framework of governance is not only intended to be internally oriented, but also includes external aspects, as well as outputs or results that will be targeted in a certain period, as well as outcomes or impacts of the implementation of good governance. Good governance is currently not only echoed at the national level, but has been echoed at the international or global level (Duadji, 2019).

Government governance that will lead to a good level of course must be promoted and advertised continuously without stopping, and this campaign must continue to be carried out in order to create a clean and authoritative government and produce dignified officials. If we want a good, strong, clean, and transparent bureaucracy, of course it is necessary to implement 
relevant and comprehensive or comprehensive reform of the apparatus and bureaucracy (Zuhro, 2010).

This is in accordance with the thoughts and pouring of ideas as well as the results of research that has been carried out by (Hakim, 2016), which states that good and clean governance in Indonesia, especially those related to the development of modern society, is something that cannot be avoided, because good governance will come from one of them good thoughts or ideas.

The implementation of good governance is one of the best concepts of offering a system in democracy. This is because the implementation of good governance has a function to direct and provide good organizational guidelines in all kinds of activities (Permatasari, 2020). One of the elements of good governance is accountability for the success or failure of the implementation of programs, targets, and targets set by the government on a regular basis. One form of good governance is obtaining a fair opinion with an exception (Jauhari et al., 2019).

In recent years, the term good governance has hit all levels of society in all corners of the archipelago. The slogan of government reform that was once very popular and energetic has been widely used. However, the discourse of good governance can still survive today, and seems to be a symbol of Indonesia's entry into the global standard of living. Villagers who do not speak English can also be fluent in reciting good governance. We can easily witness or hear up close the polite and beautiful language of 'good governance' (Prianto, 2011).

To realize optimal good government, discipline enforcement efforts are needed in order to realize clean government, which is needed in order to realize the implementation of assigned tasks and achieve professionalism of the State Civil Apparatus (ASN). It is very unlikely that the enforcement of discipline can run well, if the discipline enforcers of the state civil apparatus themselves are undisciplined and unprofessional. ASN's indiscipline and unprofessionalism will greatly impact public services in the community (Probowati \& Gunarto, 2017).

Thinking about clean governance management in organizations in one of the public sectors stems from the point of view or perspective that the form of responsiveness of leaders in good public leadership and providing good solutions to a problem is to comprehensively recognize the problem, carry out tasks well about themselves and themselves. effective, and have ideas and ideas about environmental conditions and aspirations in various problems and society(Kobalen \& Bakti, 2019). This is in line with the research submitted by (Sunardi, 2018), namely, as civil servants who serve the needs of the community, ASN must also consider various inputs, if these inputs can be useful for public service in the future.

In recent years, massive development has been taking place in Indonesia, as well as international institutions engaged in providing development assistance and assistance, actively carrying out and promoting a paradigm shift in governance and development based on the conception of good and clean governance. The concept of good governance that emerged at the end of the 20th century was a response that emerged and developed in various countries (including Indonesia), including correcting the role of the government towards governance and implementation of development oriented to the mission of community empowerment in an effort to improve social welfare. economy, and political democratization (Rasul, 2009). This is in accordance with and in line with the results of research conducted by (Indrawati, 2012) whose research results are basically the development that is currently underway and its implementation being carried out by the current government has the aim of achieving a high level of people's prosperity and giving a fairly positive impact on the realization of various aspects that support clean and good governance.

To realize a clean, authoritative and dignified bureaucracy, the existence of a bureaucratic journey as a logical consequence of the main task of the state (government) to organize social welfare must continue to be carried out properly. In this case, the state must be involved in 
producing goods and services needed by its people (public goods and services) either directly or indirectly. Even under certain circumstances it is the state that decides what is best for its people.

For this reason, the state builds a bureaucratic administrative system that aims to serve the interests of its people, it must continue to be carried out properly. Bureaucratic administration for some people is interpreted as a complicated, difficult and annoying procedure. But for others, bureaucracy is understood from a positive perspective, namely as an effort to regulate and control people's behavior so that they are more orderly. Order in question is order in terms of managing various resources that distribute these resources to every member of the community fairly (Sulistio, 2013). The management must also show that good bureaucratic capabilities greatly affect the performance of the nation as a whole (Dewi, 2016).

The implementation of clean government must continue to be developed and must be able to bring changes in the bureaucratic system in Indonesia, why is that? Because changes in the mean seat or ideas and ideas implemented by the government indicate that changes or reforms in the bureaucracy and simplification in the government structure are in the process of structuring and processing data. This is for the realization of a clean and authoritative government. Moreover, if the bureaucratic arrangement supports local wisdom, it will certainly have a positive impact on excellent and dignified public services (Prayitno, 2020). This is in accordance with the results of research developed by (Rakhmat, 2013) who explained that the demands for bureaucratic reform towards a strong and clean bureaucracy for the government's target made the archipelago's bureaucracy towards a global bureaucracy, making the world of government bureaucracy unable to stand statically in the face of various challenges and increasingly dynamic environmental turmoil.

The world of public service that is being faced by society today is an increasingly complementary condition that is running so fast along with the paradigm shift of the adult public bureaucracy. The speed of responding to the needs of public services and trying to create an innovation or new creativity to become a bureaucracy that is relevant to the times.

So far, bureaucratic services have always been shown by public service problems that are not in line with public expectations. It is feared that this will damage the bureaucratic order when the government is active in improving good and targeted public services. A good bureaucracy is a bureaucracy full of innovation and creativity in creating good services for civilians (Djani, 2015).

Based on the brief description above, we are interested in studying more deeply about the implementation of good and effective government. With the implementation of good and clean governance, it will produce good, authoritative and dignified governance management. The purpose of this study is to find out how to implement and implement a clean and good government.

\section{METHOD}

The method used in this research is deft interview, namely in-depth research or qualitative research. Where this method is considered quite effective in the midst of a pandemic that is still hitting. The method uses some literature that is relevant to the current situation. This study aims to describe and show a phenomenon related to bureaucratic reform in the dimensions of systems and procedures, with several focuses and aspects studied are service, standard requirements in service, service time required in the service process, and the complaint process if bureaucratic services are not optimal. 
The data sources of this research consist of informants, events and documents. Informants are people who are considered to know correctly a phenomenon that is the object of research. Informants in this study consisted of: Inside Government, namely the parties involved in the Bureaucratic Reform of the Regional Government of East Lombok and Outside Government, namely the parties or groups of service users, namely the general public.

Then the events, namely the circumstances that occur related to this research, and the source of the document data in the form of secondary data obtained from research sites that have been determined. Data collection techniques in this study were Observation, Interview, and Documentation Techniques.

\section{RESULT AND DISCUSSION}

Basically, the bureaucracy aims to serve the community or. There is also a bureaucracy that explains the meaning of an organizational structure that has procedures, division of labor, hierarchy, and impersonal relationships. Large organizations that run a bureaucratic system will usually have strict procedures, regulations and rules so that their operational processes tend to be less flexible. Bureaucracy is currently found in many government organizations, hospitals, companies, schools, and the military. Although there is an assumption that bureaucracy is synonymous with inefficiency, waste, and laziness, in fact a bureaucratic system is needed so that operational processes run according to the rules that have been made together (Prawiro, 2018).

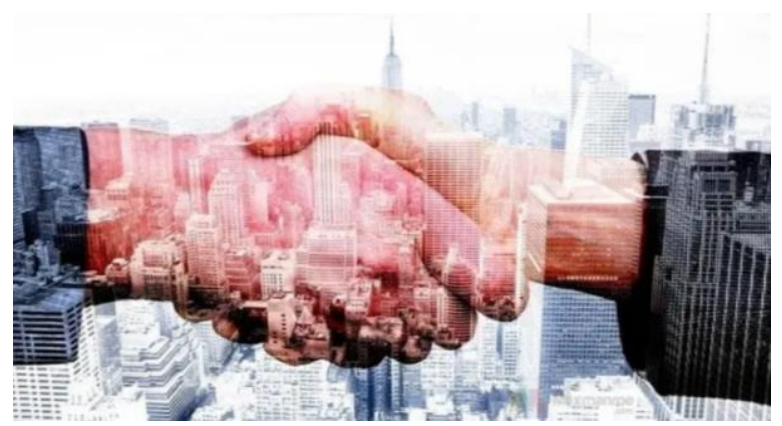

Figure 1: Illustration of clean government

Source: (Prawiro, 2018)

Good bureaucracy also makes everything about service better and more effective. The bureaucracy that results from good management arrangements will of course also produce a good bureaucracy (Ibeng, 2021).

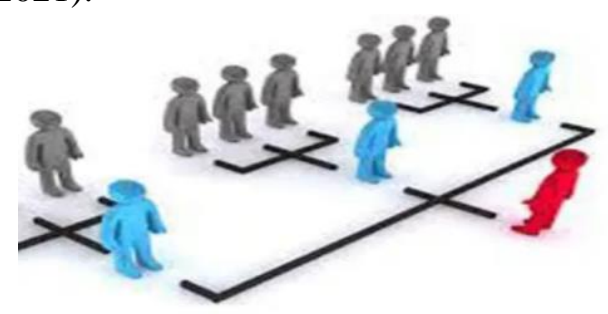

Figure 2: illustration of good and effective government Source:(Ibeng, 2021) 
Good governance of a bureaucracy will certainly have a significant impact on good public services. Basically, research on good governance and clean governance has long been a topic of discussion, and has even slowly become a culture in government, both central and regional. In the description presented above, that in implementing good governance and clean governance requires active participation from all levels of society in the location. Without the active participation of the community, the implementation of a clean and authoritative government will never be carried out properly. The principle of participation in clean governance certainly requires intensive discussion from regional leaders or local regional leaders. Participation here is like the gathering of policy makers in certain deliberation at the (minimum) sub-district level. If this planning deliberation is carried out properly, then every activity whose output or outcome will certainly be maximized.

At each deliberation, namely the Musrenbang, of course there will be access or information that will be resolved from each of these activities. This musrenbang activity is very important to hold, because ideas, ideas, positive thinking patterns, creative ideas, and discussions about what kind of development direction will be realized in order to achieve a dignified government. This is important to carry out, because the funding or funding that will be prepared jointly by the users is beneficial for the sustainability of development in a directed and sustainable manner. This is in accordance with what was expressed by (Juwitasari, Nona, Linawati, 2019) that in order to create a clean and dignified government, joint deliberation is needed to achieve what you want to aspire to from the start, and this activity must involve all elements or all parties.

In creating a good and clean government and leading to a dignified government, it certainly requires the performance and hard work of all parties. The implementation that leads to the creation of a dignified government must be pursued through good planning, regular performance reports every period, reasonable economic growth through planned activities, significant development of the human development index (HDI), as well as the emergence of innovation, creativity and good governance. which has an orderly administration, wellorganized development planning, and well-organized activities that will become its annual agenda.

The existence of provisions or regulations relating to dignified government has been described in several studies on good governance and clean government. One of them is by (Hakim, 2016) who argues that a clean and dignified government must be based on deliberation and consensus. It is a necessity that the existing provisions or regulations must be implemented consistently and sustainably, this is to provide a modern solution to a clean and authoritative government that will produce a dignified government.

The development of a paradigm or thinking about a clean and dignified government, emphasizing good administrative services, as well as serving the community sincerely and selflessly. This condition or situation must continue to be considered or implemented properly by the implementers of a policy. Especially with the current concept of serving with sincerity and avoiding extortion, this will be a real positive impact on the journey of realizing good governance.

The paradigm or view that good governance is the best system cannot be taken for granted, because this requires proof by intensive interviews and clearly requires concrete evidence in terms of the results of the performance of the state civil apparatus (ASN). Good governance also concerns government management that is neat and orderly, obeys the principles, and is fair. This will later be connected with early prevention of corruption, both politically and administratively. Therefore, realizing a clean, good and authoritative government requires a strong commitment and active participation from all parties. 
Likewise in East Lombok, the realization of a dignified government is produced or realized from the pro-active ASN in the East Lombok area. As the results of interviews with several ASN below:

"ASN in East Lombok are slowly being able to realize a clean, good, and dignified government, because the apparatus supports each other to realize good governance, as for the shortcomings in several aspects, for example the improvement of discipline that must be maintained, professionalism which is predicated quite well, must also be continue to be improved, showing that the awareness of the state civil apparatus in maintaining professional ASN has gone according to what is expected by the regional leadership". (interview with Selamet, 15 May 2021)

Likewise with other state civil servants, stated that:

"To ensure the realization and implementation of good, clean and authoritative government, good and clean ASN is also needed, such as sweeping a dirty floor, the broom must be clean first, then the floor will be clean and the atmosphere of the room will automatically be comfortable for cleaning. occupied". (interview with Sikur District Secretary, Taufik Hidayat, 17 May 2021).

Meanwhile, other officials are of the opinion as follows:

"In realizing a dignified state apparatus that begins with a good government and clean government, of course, it must first begin with the nature and character of our leaders, as long as our leaders immediately respond to suggestions and ideas and ideas that we convey for regional progress. For ourselves, of course, we can realize the dream of realizing a dignified government slowly." (interview with Head of Village Administration, Baiq Windi, 18 May 2021)

From the results of the information above with several informants, namely three people, a common thread can be drawn that the implementation of good governance involves government management activities that are responsible and in line with democracy and efficient bureaucratic mechanisms, as well as related to preventing corruption, both politically and politically. administratively. For this reason, the paradigm of good governance can work well if the mechanism of democracy is a system that underlies participation and can encourage a sense of justice for the public interest.

In practice, the realization of clean government and good governance that leads to an effective and dignified bureaucracy must of course be followed by a good planning and supervisory function and are continuously practiced, in order to create a clean and good culture that is manifested every time. Of course, this is done by means of how the leaders in each SKPD go directly to the community to ensure the realization of good and clean governance (Sunardi, 2018).

In the East Lombok Regional Government as the research location, the research team showed that the implementation of good and clean governance depends on how the SKPD leaders or each department head go down to absorb the aspirations in the field, which in the future is certainly expected to create input and suggestions for improvement. bureaucracy to a dignified bureaucracy. In addition, the self-awareness of bureaucrats who want to create a dignified bureaucracy must also be followed by subordinates (top down) who are ready to provide good services for the creation of a clean and good government.

The concept of a dignified bureaucracy actually seeks to apply organizational principles that are intended to improve administrative efficiency, even though bureaucracy often causes bad effects. Usually complex and complicated administrative problems are found in large 
organizations, such as government organizations. However, the actual bureaucracy is not limited only to public sector institutions, but also to the private sector (Sulistio, 2013).

The bureaucratic order in the East Lombok Regional Government shows that changes in the method of realizing a dignified bureaucracy must begin by referring to the SOP or Standard Operating Procedures of each SKPD, because from this SOP it becomes a reference or benchmark than the state civil apparatus will work and produce optimal performance.

Good governance arises with the desire or motivation to be achieved by the East Lombok Regional Government in order to organize good and clean governance. This is inseparable from the need for good synergy between academics and the bureaucracy that leads a region. A theory of development is certainly needed in developing the region, but the implementation of development activities is also important and much needed to make this happen (Prianto, 2011).

\section{CONCLUSION}

In the midst of the government's efforts to promote a healthy bureaucracy, there are also challenges that lead to maturity in formulating policies so that the implementation of a healthy and dignified bureaucracy can be realized. This study proves that theory and application cannot be separated and do not occur automatically, because they still require improvements to standard operating procedures or SOPs that need to involve stakeholders as a basis or reference in carrying out public services in order to create a dignified bureaucracy. Aspects that need to be considered in order to improve standard operating procedures or SOPs in public services include: mapping problems in the office and scheduling regular field visits, certainty of service schedules, service procedures, speed of service officers, discipline of service officers.

\section{REFERENCES}

Dewi, R. (2016). Membangun Birokrasi Yang Profesional. Perspektif, 2(1), 41-46. https://doi.org/10.31289/perspektif.v2i1.106

Djani, W. (2015). Reformasi Birokrasi Pada Dimensi Sistem Dan Prosedur Dalam Pelayanan Perizinan Terpadu Di Pemerintahan Kota Kupang. Spirit Publik, 10(2), 91-114.

Duadji, N. (2019). Good Governance Dalam Pemerintahan Daerah. MIMBAR, 28(2), 201-209. https://doi.org/10.35724/mjpa.v1i2.1985

Hakim, A. (2016). Dinamika Pelaksanaan Good Governance Di Indonesia (Dalam Perspektif Yuridis dan Implementasi). Civil Service, 10(1), 15-34.

Ibeng, P. (2021). Pengertian Birokrasi, Ciri, Jenis, Karakteristik dan Perannya. https://pendidikan.co.id/tag/pengertian-birokrasi-kampus/.

Indrawati. (2012). Prinsip Good Financial Governance Dalam Pengelolaan Keuangan Negara Dalam Rangka Mewujudkan Clean Governance. PERSPEKTIF, XVII(3), 201-211.

Jauhari, H., Sari, Y., \& Dewata, E. (2019). Implementation of Good Governance, Utilization of Information Technology and Reliability of Government Financial Statement. Journal of Accounting and Strategic Finance, 2(2), 117-126. https://doi.org/10.33005/jasf.v2i2.59

Juwitasari, Nona, Linawati, S. (2019). Penerapan Prinsip Good Governance dalam Pengelolaan Alokasi Dana Desa ( Studi pada Desa Kampungbaru, Kecamatan Kepung, Kabupaten Kediri ) Oleh: Dibimbing oleh: Universitas Nusantara Pgri Kediri Surat Pernyataan Artikel Skripsi Tahun 2019. unpkediri. 
Kobalen, A. S., \& Bakti, A. F. (2019). Good clean governance (GCG) dalam kepemimpinan Basuki Tjahaja Purnama (Ahok) sebagai Gubernur DKI Jakarta ditinjau dari perspektif asta brata. Publisia: Jurnal Ilmu Administrasi Publik, 4(1), 81-101. https://doi.org/10.26905/pjiap.v4i1.2272

Permatasari, I. A. (2020). Kajian Penerapan Prinsip Good Governance Pemerintah Kabupaten Lebak. Jurnal Kebijakan Pembangunan Daerah, 4(1), 33-48.

Prawiro, M. (2018). Pengertian Birokrasi: Arti, Ciri-Ciri, Fungsi, dan Peran Birokrasi. https://www.maxmanroe.com/vid/sosial/pengertian-birokrasi-adalah.html.

Prayitno, B. (2020). Birokrasi Dan Politik: Problematika Dalam Keniscayaan Administrasi Publik. Jurnal Wacana Kinerja: Kajian Praktis-Akademis Kinerja dan Administrasi Pelayanan Publik, 14(1), 133-149.

Prianto, A. L. (2011). Good Governance dan Formasi Kebijakan Publik Neo-Liberal. Otoritas : Jurnal Ilmu Pemerintahan, 1(1), 1-10. https://doi.org/10.26618/ojip.v1i1.11

Probowati, N., \& Gunarto. (2017). Penerapan Penegakan Hukum Disiplin Polri Demi Terwujudnya Good Governance and Clean Goverment Dalam Ruang Lingkup Polda Jawa Tengah. 12(3), 601-610.

Rakhmat. (2013). Reformasi Birokrasi Publik Dalam Perspektif Good Governance. Jurnal Paradigma, 2(1), 1-9.

Rasul, S. (2009). Penerapan Good Governance di Indonesia dalam Upaya Pencegahan Tindak Pidana Korupsi. Mimbar Hukum - Fakultas Hukum Universitas Gadjah Mada, 21(3), 538553. https://doi.org/10.20303/jmh.v21i3.318

Sulistio, E. B. (2013). Konsep Birokrasi (hal. 1-21).

Sunardi. (2018). Fungsi Pengawasan Dpr Terhadap Pemerintah Dalam Mewujudkan Good Governance Dan Clean Government Ditinjau Dari Perspektif Politik Hukum. Jurnal Meta Yuridis, 1(2), 23-35.

Zuhro, R. S. (2010). Good Governance dan Reformasi Birokrasi di Indonesia. Jurnal Penelitian Politik, 7(1), 1-21. 